\title{
TEACHERS' SELF-CONCEPT, TASK PERCEPTION, AND JOB PERFORMANCE IN SELECTED SCHOOLS OF DISTRICT III DIVISION OF NEGROS OCCIDENTAL
}

"Dr. Roxanne M. Rivera

Paper Received: 04.03.2020 / Paper Accepted: 27.05.2020 / Paper Published: 01.06.2020
Corresponding Author: Dr. Roxanne M. Rivera; Email: roxanne.rivera@ chmsc.edu.ph ; doi:10.46360/globus.xxxxxxxx

\begin{abstract}
This study focused on the teachers' levels of self-concept, task perception, and job performance in the selected public high schools with at least a population of 50 teachers in District III, Division of Negros Occidental during the School Year 2015-2016. The sample size of 214 respondents was determined using the Yamane's Formula. This study utilized both self-made and standardized questionnaire in gathering the data. The validity rating is 4.75 . The reliability rating is 0.777 . Computations were processed through the SPSS. The statistical tools that were used using the SPSS were frequency count and percentage rating, the mean, the Mann Whitney $U$ and the Spearman Rho. Based on the gathered data, the following are results of the study. It was found out that the respondents' levels of self-concept when grouped according to age, sex, civil status, average family monthly income, and educational attainment were very high. The result of the respondents' levels of task perception when grouped according to age, sex, civil status, average family monthly income, and educational attainment, the result were very high. Moreover, the respondents' level of job performance when grouped according to age, sex, civil status, average family monthly income, and educational attainment, showed high results. Lastly, there was a significant relationship between the respondents' levels of self-concept and task perception. On the contrary, there were no significant relationships between the respondents' levels of self-concept and job performance, and task perception and job performance.
\end{abstract}

Keywords: Self-concept, Task Performance, Job Performance.

\section{Introduction}

Republic Act No. 4670 also known as the Magna Carta for Public School Teachers highlights that the public school teachers' social and economic living and working conditions, their terms of employment and career prospects should be improved because education is an essential factor in the economic growth of the nation. Indeed, being the bearer of knowledge is not an easy profession. Therefore, it takes great courage and wisdom to be a great teacher in order to have successful students. Gratefully, the Department of Education and Commission on Higher Education are doing their best to improve the living and working conditions of the teachers and the students. However, the Philippine education is still invisible in the global academic arena. Teachers as the forefront of the system, they should be endowed with excellent skills and positive personality as the helper of students' competences. Three of the important factors to be considered should be the self-concept, task perception, and job performance.

Self-concept is the mental image one has of oneself (Merriam-Webster, 2017). In order to have a satisfying life, it is ideal that the person should be aware of the self-images that one has possessed. It is believed that the more a person is aware of him/herself, the more self-actualized he or she would be. Thus, the individual would face any adversities in life with courage and ease and he or she will be mindful of his or her actions. This would lead to a fulfilling life, and in return, the individual would treat others kindly with a positive attitude. As a teacher, one should be aware of one's self-concept, because it would help him or her assess his or her manner of teaching in congruence to their personality. In this regard, there will be a win-win situation in the classroom. The students will learn more from their satisfied teacher and the school administrators will be pleased with their teacher, thus, they will support him or her in any way they can.

On the other hand, task perception is the manner of observing and analyzing the task one has given. Although teaching is one of the most noble jobs a person could have, it is undeniable that it is also one of the hardest professions. A teacher will juggle tasks for the students, colleagues, and the demands of the school administrators. 
Moreover, it is important to assess whether the teacher is performing well in and out of the classroom. Thus, the Individual Performance Commitment and Review Form of the Department of Education is a good tool to evaluate teachers' performances. A teacher's performance will have a great impact in the success of the school because a teacher is a major catalyst of holistic development.

It is no easy feat to work in an environment that deals with children's lives. A teacher could either break or make the future of the child. The researcher, as a college teacher who is also passionate about teaching, finds it odd to know that there are high school graduates who cannot even read and spell basic words. This could be a major threat in the Philippine academe. To begin this great educational reform, it is a must to start with the educators - the foundations of learning. The researcher believes it is important to focus on the teacher's personality and manner of teaching. So, as a warrior of high quality education, it is the researcher's desire to change the academe for the better, especially in the selected public high schools of District III, Division of Negros Occidental. To begin this educational reform, it is a must to start with the educators as the main foundation of learning, focusing on the self-concept, task perception, and job performance of teachers, hence, this study.

\section{Hypotheses}

Statement of the Problem

This study aimed to find out the teachers' selfconcept, task perception, and job performance in the selected public high schools in District III, Division of Negros Occidental.

Specifically, this study sought to answer the following questions:

1. What is the teachers' level of self - concept according to the following variables?
a) age
b) $\operatorname{sex}$
c) civil status
d) average family monthly income
e) educational attainment

2. What is the teachers' level of task perception according to the aforecited variables?

3. What is the teachers' level of job performance according to aforecited variables?

4. Is there a significant relationship between the self-concept and task perception of teachers?

5. Is there a significant relationship between the self-concept and job performance of teachers?

6. Is there a significant relationship between the task perception and job performance?

\section{Hypotheses of the Study}

Based on the preceding problems, the following hypotheses will be tested:

1. There is no significant relationship between the self-concept and task perception of teachers.

2. There is no significant relationship between the self-concept and job performance of teachers

3. There is no significant relationship between the task perception and job performance of teachers.

\section{Materials and Methods}

\section{Research Design}

The descriptive correlation research design was utilized in this study. This design was considered appropriate by the researcher because the investigation sought to identify the levels and significant relationships of self-concept, task performance, and task perception of public high school teachers of District III, Division of Negros Occidental. Besides, this design is appropriate because descriptive correlation research is designed to determine the correlation, or the degree of relationship, between two traits, behaviors, or events. When two things are correlated, changes in one are associated with changes in another (Myers \& Hansen, 2012).

\section{Locale of the Study}

This research was conducted in the selected public high schools in District III, Negros Occidental. The chosen locality has two major cities: Talisay City which is located between Bacolod City on the south and Silay City on the north.

\section{Respondents of the Study}

This study focused on the teachers' levels of selfconcept, task perception, and job performance in the selected public high schools with at least a population of 50 teachers in District III, Division of Negros Occidental.

The 462 total respondents of this study were too large to be managed by the researcher. Thus, the researcher opted to determine the number of respondents through sample survey with the use of stratified sampling technique. The sample size of 214 respondents was determined using the Yamane's Formula. Table 1 reflects the actual respondents of the study by cluster.

\section{Data Gathering Instrument}

This study utilized both self-made and standardized questionnaire in gathering the data. The self-made questionnaire consisted of two parts:

The first part contained the personal information of the respondent's age, average family monthly 
income, sex, civil status, and highest educational attainment.

The second part was the questionnaire proper that consists of fifteen (15) items each for the levels of self-concept and task perception. While raw data for the job performance was retrieved from the School's ICPRF.

For the levels of self-concept and task perception, the respondents were asked to rate each item using the 5-point Likert Scale which contained the following scores: 5 for "Strongly Agree," 4 for "Agree," 3 for "Undecided," 2 for "Disagree," and 1 for "Strongly Agree." Lastly, for the Level of Job Performance, the Individual Performance and Commitment Review Form (IPCRF) was utilized.

The rating scale and qualitative description for the levels of self-concept, task perception, and job performance of the public high school teachers.

\begin{tabular}{llll}
\hline $\begin{array}{l}\text { Level of } \\
\text { Self- } \\
\text { concept }\end{array}$ & $\begin{array}{l}\text { Level of } \\
\text { Task } \\
\text { Perception }\end{array}$ & $\begin{array}{l}\text { Level of } \\
\text { Job } \\
\text { Performance }\end{array}$ & Scale \\
\hline Very & Very High & Outstanding & $4.24-$ \\
High & & & 5.04 \\
High & High & Very & $3.43-$ \\
& & Satisfactory & 4.23 \\
Average & Average & Satisfactory & $2.62-$ \\
& & & 3.42 \\
Low & Low & Unsatisfactory & $1.81-$ \\
& & & 2.61 \\
Very & Very Low & Poor & $1.00-$ \\
Low & & & 1.80 \\
\hline
\end{tabular}

\section{Validity of the Research Instrument}

The questionnaires were subjected to jury validation. The criteria that were used by the jurors in evaluating the instruments were those of Good and Scates. The four validators were research experts and holders of appropriate doctorate degrees in the field of psychology, education, and management. The validity rating is 4.75 , interpreted as "Very Good".

\section{Reliability of the Research Instrument}

Myers and Hansen (2012) stated that reliability refers to the consistency and dependability of experimental procedures and measurements, and the extent to which a survey is consistent and repeatable. After establishing the validity of the questionnaire, and to ensure that the questionnaire is clear, understandable, and has the property to elicit stable and consistent answers from the respondents, a test of reliability was conducted to 30 high school teachers. Subsequent to the retrieval of questionnaires, the results were then analyzed and interpreted using the Cronbach Alpha in the
SPSS. The reliability rating is 0.777 , interpreted as highly reliable.

\section{Data Gathering Procedure}

The researcher first sought the approval of The Division of Negros Occidental Head, for the conduct of study. Then, after administering the questionnaire to the selected public high school teachers and retrieving of data, the researcher together with the statistician tabulated and processed the data by classifying the teachers according to their age, sex, civil status, average family monthly income, and educational attainment.

As to variables, sex was categorized as male and female, age as younger (38 years old and below) and older (39 years old above), civil status as single and married, average family monthly income as lower (23,000 and below) and as higher (over 23,000 ), educational attainment as higher (doctoral degree holders, doctoral degree holders is on-going, master's degree holder) and as lower (master's degree is on-going, and college graduate).

The level of self-concept was grouped according to areas: self-image, self-worth, and ideal self. While the level of task perception was grouped according to the following areas: working with students, working with fellow teachers, and working with the school administrators. Lastly, the level of job performance was measured using the Individual Performance Commitment and Review Form (IPCRF) with the following areas: teachinglearning process, pupils/students outcomes, community involvement, and professional growth and development.

\section{Analytical Schemes}

The study employed three analytical schemes based on the research objectives which were descriptive, comparative, and relational.

\section{Statistical Tools}

The following statistical tools in SPSS were used in the analysis of data. For Problem Nos. 1, 2 and 3 the mean was used to determine the levels of selfconcept, task perception, and job performance. For Problems 4, 5, and 6 which measure the significance of the relationship between levels of self-concept, task perception, and task performance of respondents, Spearman Rho was utilized. It is an appropriate statistical tool in determining relationships between variables that are either interval or ratio.

\section{Result}

Based on the gathered data, the following are results of the study. It was found out that the 
respondents' levels of self-concept on the areas of self-image, self-worth, and ideal self were very high. Also, the respondents' levels of self-concept when grouped according to age, sex, civil status, average family monthly income, and educational attainment were very high. The result of the respondents' levels of task perception on the areas according to working with students and working with fellow teachers were very high. On the other hand, the result of the respondents' level of task perception according to working with the school administration was high. When respondents' level of task perception where grouped according to age, sex, civil status, average family monthly income, and educational attainment, the result were very high. Moreover, the respondents' level of job performance according to teaching - learning process, pupils/students outcomes, community involvement, and professional growth and development showed high results. When the respondents' levels of job performance where grouped according to age, sex, civil status, average family monthly income, and educational attainment, it showed high results. Lastly, there was a significant relationship between the respondents' levels of self-concept and task perception. On the contrary, there were no significant relationships between the respondents' levels of self-concept and job performance, and task perception and job performance.

\section{Conclusion and Recommendations}

Based on the research findings the following conclusions were drawn:

The teachers had high level of self-concept and positive high regard with themselves regardless of meager salaries. The teachers still manage to value themselves very highly. Truly, there is no greater glory in teaching than to be respected and honored by the students. In terms of task perception, the teachers' discernments on teaching were very high, which connotes that they have positive teaching attitude when dealing with students, fellow teachers, and school administrators. Indeed, teachers in the Philippines have high regard of having a harmonious relationship and good camaraderie in their working environment. It also showed that teachers had very satisfactory level of job performance using the Department of Education's IPCRF. This means that teacher respondents were worthy to continue their teaching job since they showed high ratings in terms of teaching - learning process, pupils/students outcomes, community involvement, and professional growth and development. On the basis of significant relationships, it showed the importance of self-concept and task perception. Therefore, task discernments of the respondents rely on the levels of their self-concept.
In the light of the results of this study, the researcher presents the following recommendations.

Teachers should be more knowledgeable of their self-concept, because having a healthy outlook of the self would guarantee a happier relationship in both personal and professional life. They should engage in activities that would further develop their self-concept such as: morning and evening meditation, yoga exercises, positive journal or diary writing, and joining in self-development seminars and workshops.

Further, having a positive self-concept would result to unprejudiced discernment on working with students, fellow teachers, and school administrators. To develop an optimistic judgment with in the school, teachers should actively participate in every school activities. Involving oneself to various academic events would enhance the manner of perceiving tasks.

Teachers who have optimistic outlook about themselves would guarantee an outstanding job performance evaluation. To enhance job performance, teachers should: First, remove work disruptions, take brief work breaks, and get enough sleep. Second, the teacher should set everyday goals for proper time management. Third, organize everything at home and at work, there is nothing more relaxing than having a neat and clean environment. Fourth, keep a healthy diet. Lastly, have a good chat with good friends and families, stressors can be manage through constant communications with love ones.

The school administrators should invest more on relevant trainings that would enhance the teachers' personal and professional life, such as the following: Leadership Seminar-Workshop, Stress Management Seminar-Workshop, Team Building Training, Communication and Conflict Resolution Seminar, Performance Appraisal SeminarWorkshop, and lastly, the Time Management and Motivation Seminar-Workshop.

Furthermore, the Department of Education, Commission of Higher Education, should review their policies on salary standardization to suit the modern life of the teachers.

Finally, the future researchers should focus on the other aspects of self-concept such as the self-image, self-worth, ideal self, self-esteem, and task perception. Aside from further exploring the other factors of job performance, they should also choose respondents from all private and public schools in the District III, Division of Negros Occidental for a bigger sample. 


\section{Conflict of Interest}

There is no Conflict of Interest in this work.

\section{References \\ Books}

1. Aglubat, Linofe R., Gazzingan, Leslie B. Guerrero, Manuel R., and Tomas, Rodrigo D.P., (2005). "General Psychology: Human Behavior in Perspective". Grandwater Publications and Research Corporation. Makati.

2. Ardales, Venancio. (2008). "Basic Concepts and Methods in Research". Manila Educational Publishing House.

3. Franzoi, Stephen L., (2003). Social Psychology Third Edition. McGraw Hill, N.Y.

4. Kosslyn, Stephen M. and Rosenberg, Robin S., (2005). Fundamentals of Psychology: The Brain. The Person, The World, Pearson Education, Boston.

5. Lahey, Benjamin B., (2001). Psychology: An Introduction Seventh Ed. McGraw Hill, N.Y.

6. Miranda, Gregorio S. and Gow, Carmelita M., (2005). Office Management: Principles and Practices $4^{\text {th }}$ Edition. National Bookstore, Mandaluyong.

7. Myers, Ann and Hansen, Christine H., (2012). Experimental Psychology. Cengage Learning Asia. Singapore.

8. Smith, Edward E. Hoeksema, Susan Nolen, Fredrickson, Barbara, and Loftus, Geoffrey R., (2003). Atkinson and Hilgard's Introduction to Psychology $14^{\text {th }}$ Ed. Thomson and Wadsworth, Singapore.

\section{Electronic Sources}

1. Agarwal, Ankita, (2017). Theories of Performance Management System. Retrieved February 22, 2017 from https://www.projectguru.in/publications/model s-and-theories-of-performance-managementsystem/

2. Antecol, Heather, Eren, Ozkan and Ozbek, Serkan, (2017). The Effect of Teacher Gender on Student Achievement in Primary School: Evidence From Randomized Experiment. Retrieved on May 23, 2017 from http://ftp.iza.org/dp6453.pdf

3. Bruening, Thomas H. and Hoover, Tracy S., (2017). Personal Life Factors as Related to Effectiveness and Satisfaction of Secondary Agricultural Teachers. Retrieved May 23, 2017 from http://pubs.aged.tamu.edu/jae/pdf/Vol32/3204-37.pdf

4. Craven, Rhonda G., (2008). Why Self-Concept Matters for Teacher Education: Examples from Performance, Mathematics and Reading, and
Aboriginal Studies Research. Retrieved on March 1, 2017 from https://www.researchgate.net/publication/2285 12859_Why_Self-

Concept_Matters_for_Teacher_Education_Exa mples_from_Performance_Mathematics_and_ Reading_and_Aboriginal_Studies_Research Drago, Francesco, Self-Esteem and Earnings. IZA Discussion Paper No. 3577.

Retrieved on May 1, 2017 from https://ssrn.com/abstract $=1158974$ or http://dx.doi.org/10.1111/j.00427092.2007.00700.x.

5. Dockery, Alfred M., (2017). Education and Happiness in the School-to-Work Transition. Retrieved April 3, 2017 from http://files.eric.ed.gov/fulltext/ED509308.pdf.

6. Goksoy, S. \& Akdag, S.K., (2014). Primary and Secondary School Teachers' Perceptions of Workload. Creative Education, 5, 877-885. http://dx.doi.org/10.4236/ce.2014.511101

7. https://errolgatumbato.files.wordpress.com/201 4/01/negros-occ-map.jpg.

8. https://www.vocabulary.com/dictionary/age.

9. https://www.quora.com/What-does-the-termCivil-Status-mean.

10. http://dictionary.cambridge.org/dictionary/engl ish/sex.

11. http://www.perceptuallearning.com/plearn.php.

12. https://www.reference.com/worldview/descriptive-correlational-method.

13. https://explorable.com/correlational-study

14. http://www.negros-occ.gov.ph/about-negrosoccidental/cities-and-municipalities.

15. http://www.edweek.org/ew/articles/2015/03/25 /new-studies-find-that-for-teachersexperience.html.

16. Job Performance. Retrieved February 22, 2017 from http://www.businessdictionary.com/ definition/job-performance.html

17. McLeod, S. Self Concept, (2008). Retrieved from http://www.simplypsychology.org/selfconcept.html.

18. Muhammad Amin,Rahmat ullah Shah,Muhammad Ayaz,Malik Amer Atta, Teachers' Job Performance At Secondary Level In Khyber Pakhyunkhwa, Pakistan. Retrieved from http://link.springer.com/referenceworkentry/10 .1007\%2F978-1-4419-1005-9_900).

19. Perception. Retrieved February 22, 2017, from http://medicaldictionary.thefreedictionary.com/ Perception+(psychology).

20. Quality Education, (2015). United Nations Educational Scientific and Cultural Education [UNESCO]. Reterieved from www.UNESCO.com

21. "Rogers' Humanistic Theory of Personality." Retrieved May 26, 2016, From https://www.boundless.com/psychology/textbo 
oks/boundless-psychology-

textbook/personality-16/humanistic-

perspectives-on-personality-78/rogers-

humanistic-theory-of-personality-308-12843/

Task. Retrieved February 22, 2017, from

http://www.businessdictionary.com/definition/t ask.html

22. Teacher. Retrieved March 30, 2017, from https://www.merriam-

webster.com/dictionary/teacher

23. The Perception of Workload and Task Complexity and its influence on Students: Approaches to Learning a Study in Higher Education. European Journal of Psychology of Education 26(3):393-415 - September

2011retrieved

fromhttps://www.researchgate.net/publication/ 225585003_The_perception_of_workload_and _task_complexity_and_its_influence_on_stude nts\%27_approaches_to_learning_A_study_in_ higher_education

24. Zlatkovic, Blagica, Stojiljković, Snežana, and Djigić, Gordana. Self-concept and Teachers' Professional Roles. Retrieved on May 1, 2017 from http://www.sciencedirect.com/science /article/pii/S1877042812054092

\section{Journals}

1. Glotova, G., and Wilhelm, A., Teacher's selfconcept and self-esteem in pedagogical communication. Retrieved from http://psycnet.apa.org/journals/bul/90/1/125/

2. Usop, A.M., Kadtong M.L. and Usop, A.S.O., (2016). The significant relationship between work performance and job satisfaction in Philippines. International Journal of Human Resource Management and Research (IJHRMR), 3(2); 9-16.

3. Inayatullah, Atiya and Jehangir Palwasha. Teacher's Job Performance: The Role of Motivation. Abasyn Journal of Social Sciences 5(2). Retrieved from http://www.mtstcil.org/skills/image-1.html)

4. Ilin, Gulden, Inozu, Julide and Yumru, Hulya, (2007). Teachers' and Learners' Perceptions of Tasks: Objectives and Outcomes. Journal of Theory and Practice in Education, 3(1); 60-68. Retrieved from https://eric.ed.gov/?id=ED 502018.

5. Bentea Cristina-Corina and Anghelache Valerica, (2011). Teachers' perceptions and attitudes towards professional activity. World
Journal of Education, 1(1), Retrieved from https://www.researchgate.net/publication/2577 16090_Teachers\%27_Perceptions_and_Attitud es_Towards_Professional_Activity.

6. Agarwal, Nidhi and Jaiswal, Sushma, (2018). "A Study on Job Satisfaction Among Female Teachers". Globus An International Journal of Management \& IT, 2018, 9(2), 1380-1382; doi: 10.5281/zenodo.3806127.

7. Agarwal, Nidhi and Gupta, Ruchika, (2011). "Role of Technology for the Efficiency of HR Management", Information and Communication Technology: Challenges \& BusinessOpportunities, Excel India Publishers, Delhi; 174-176, ISBN: 93-80697-95-3.

8. Attar, Appalal, (2019). Eithcs and English Language Teaching Objectives. Globus Journal of Progressive Education, 9(2); 11-4, doi: 10.46360/globus.9.2.2020.11-14.

9. Luyten, L., Tuerlinkx, F. and Lowyck, J., (2001). Task perception as a mediating variable: A contribution to the validation of instructional knowledge. British Journal of Educational Psychology, 71(2); 203-223. Retrieved from http://onlinelibrary.wiley.com/ doi/ 10.1348/ 000709901158488/abstract. .

10. Perkins, D. and Zimmerman, M., (1995). Empowerment theory, research, and application. American Journal of Community Psychology 23; 569-580.

11. Zeng, Xihua, Li, Weiwei, Wang, Yun Li, Jie Huang, Xiaorui and Li, Xinjao, (2017). Normative Importance of Money, Family Income, and Self-Esteem: A Multilevel Latent Modeling Analysis of Data from Chinese Early Adolescents. 130(3); 1247-1262. Retrieved from https://link.springer.com/article /10.1007/s11205-016-1243-3

\section{Thesis}

1. Flores, Maria B., (1995). The levels of Performance of teachers and students at the Biniculi National High School: A correlation study. Thesis. West Negros College Bacolod City. MAED.

2. Babor, Rogelio L., (1991). Level of Teaching Performance of Private Secondary School Teachers in the Municipality of Victoris, Negros Occidental during the school year 1990-1991. Thesis, West Negros College Bacolod City. MAED.

How to cite this article:

Rivera, Roxanne M., (2020). Teachers' Self-Concept, Task Perception, and Job Performance in Selected Schools of District III Division of Negros Occidental. Globus Journal of Progressive Education, 10(1): 76-81. 